\title{
Forest seed dispersal by carnivores in temperate forests and dry tropical forests
}

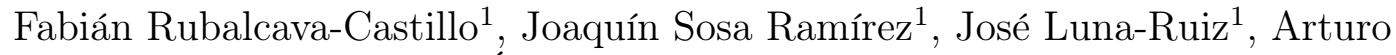 \\ Valdivia-Flores $^{1}$, and Luis Íñiguez-Dávalos ${ }^{2}$ \\ ${ }^{1}$ Universidad Autónoma de Aguascalientes \\ ${ }^{2}$ Universidad de Guadalajara Centro Universitario de la Costa Sur
}

October 5, 2020

\begin{abstract}
The mechanisms of forest seed dispersal and regeneration of various altered forest ecosystems are complemented by the action of carnivores. The objective of this study was to evaluate the role of endozoochoric and diploendozoochoric mammals in the dispersal, scarification, and germination of seeds in two different forest ecosystems: temperate forest (TF) and dry tropical forest (DTF). A direct search and scat collection were carried out to determine dispersing agents and the abundance and richness of seeds in the Protected Natural Area, Sierra Fría, Aguascalientes, Mexico. Viability was evaluated by means of X-rays and a germination test using an optical densitometry. In addition, thickness measurements and observations were made on the surfaces of the testas by a scanning electron microscopy. In the TF, four plant species were dispersed, mainly Arctostaphylos pungens (P $<0.05)$, by four mammals, where the gray fox dispersed the highest average $(66.8 \pm 68.2 ; \mathrm{P}<0.05)$ and diploendozoochory was detected in bobcat scats associated with rabbit hair (Sylvilagus floridanus). The DTF presented higher abundance and richness of species, where Myrtillocactus geometrizans had the highest abundance $(2680 \pm 4423)$ and the coati $(\mathrm{P}<0.05)$ dispersed the highest number of seeds $(8639 \pm 12203)$. In both types of forest, endozoochory and diploendozoochory did not affect the viability, the thickness of the testas, or the germination of any species of seeds. These results suggest that dispersing carnivores adapt to the abundance and richness of seeds in the forests they inhabit, thus developing an important ecological function by dispersing, scarifying and promoting the selective germination of seeds with thick testas in TF and thin testas in DTF.
\end{abstract}

\section{INTRODUCTION}

Endozoochory is a long-distance seed dispersal system by animals. Thus, for seeds dispersed in this manner to survive and germinate, their cover must be hard and thick enough to resist passage through the animals' digestive tracts (Venier et al., 2012). Carnivorous mammals have been less studied as seed dispersers than birds or bats, although it is well known that they also consume large quantities of fleshy fruits and are capable of dispersing viable seeds of a wide variety of plant species (Stoner et al., 2007; Matias et al., 2010). Within mammals, those that carry out the diploendozoochory process are even far less studied; diploendozoochory is a seed dispersal mechanism that involves the ingestion of plant seeds by two or more different species of animals in sequence, where the participation of a carnivore in the second phase of the dispersal process can influence the plant in three ways: by transporting the seeds, altering their viability, and changing the quantity dispersed (Hämäläinen, 2017).

Endozoochory can influence plant distribution patterns (Haarmeyer et al., 2010) by facilitating the arrival of seeds in new habitats for establishment (Traveset et al., 2007). The success of this type of dispersal and its influence on the recruitment of new plants depend on the number of seeds dispersed by the animals, the survival of the seeds after digestion by the animals, and the probability of germination, which in turn depends on the soil and environmental conditions for the survival and establishment of seedlings (Schupp 
et al., 2010; Venier et al., 2012). Although the absolute number of viable seeds dispersed is an important factor, the analysis of qualitative and quantitative components of dispersion is important to understand these complex processes (Schupp et al., 2010).

The survival and germination of seeds after passage through the digestive tracts of animals are critical phases during which the seeds are subject to several potentially harmful processes (Varela \& Bucher, 2006; D'hondt \& Hoffmann, 2011), such as the wear of the testas and the breaking of the physical dormancy period of the hard seeds of some plant species. The above processes can alter the seed coat and promote mechanical or chemical scarification, increasing the probability of germination (Peco et al., 2006), or else the death of the seed if the embryo has been damaged (Campos et al., 2008). Although the hardness and thickness of a seed coat are important characteristics for seed survival and germination after passage through the digestive tract, the real effects of passage through the tract on the structure of seed coats have been little explored in the literature (Venier et al., 2012). Recently, scanning electron microscopy (SEM) has been used to observe changes in seed coats, a consequence of dispersal processes, as in the case of Schaumann \& Heinken (2002), where they explained changes in the seed coats of seeds dispersed by the endozoochory process. Also, Costea et al. (2016) applied SEM to observe how the seeds of the speciesCuscuta pacifica, dispersed by birds, presented fragmentation and complete elimination of their outer layers.

Seed dispersal by carnivores influences the recruitment of various plant species in temperate forests (Koike et al., 2008) and tropical forests (Chakravarthy \& Ratnam, 2015; Zhou et al., 2008), that is, the seeds dispersed by these types of mammals often lead to the establishment of plants (Howe \& Miriti, 2000). However, data on dispersal by carnivores in other ecosystems such as temperate forests (TF) and dry tropical forests (DTF) are scarce (Godínez-Alvarez et al., 2007). Rubalcava-Castillo et al. (2020) have shown the quantitative and qualitative contribution of mammals in the dispersal of the seeds of Arctostaphilos pungens and Juniperus deppeana in TF. Likewise, Schaumann \& Heinken (2002) described the surfaces of the testas of the seeds of the Vaccinium myrtillus species, finding through SEM that the control seeds had their cell walls intact, while those dispersed by martens (Martes martes) presented testas with damaged cell walls due to scarification by this animal.

On the other hand, Zarco-Mendoza et al. (2018) described numerous species of plants and carnivores that, in the DTF of North America, are involved in fruit-frugivorous interactions. These authors found the seeds of 18 plant species in 384 scats of mammalian carnivores, concluding that carnivores can disperse seeds in abundance and intestinal passages can have varying effects on different plant species, favoring or deteriorating the germination of their seeds, as well as dispersal to and colonization of distant areas and ecosystems. In particular, the Sierra Fría Protected Natural Area (ANP-SF) in the state of Aguascalientes, Mexico is made up of different types of ecosystems, including TF (Sosa-Ramírez et al., 2015) and DTF (Argumedo-Espinoza et al., 2018). The objective of this study was to evaluate the role of carnivorous mammals in the dispersal of seeds in different forest ecosystems, namely temperate forest and dry tropical forest.

\section{MATERIALS AND METHODS}

Study site

The study was carried out in two TF areas and one DTF area in ANP-SF, which is located in the western zone of the state of Aguascalientes, Mexico. The TF has a temperate subhumid climate and experiences summer rainfall (Rzedowski, 1978), with an average annual rainfall of $650 \mathrm{~mm}$ (SEDESO, 1995). The natural plant communities in the TF are composed of pointleaf manzanita or pingüica (Arctostaphylos pungens ), checkerbark juniper or táscate (Juniperus deppeana), strawberry tree or madroño (Arbutus sp .), oak (Quercus potosina), Pinus leiophylla var. Chihuahuana, and Pinus teocote, among others (Díaz-Núñez et al., 2016). DTF has an average annual rainfall of $625 \mathrm{~mm}$ (Sosa-Ramírez, 1998). The plant communities are composed of garambullo (Myrtillocactus geometrizans ), palo bobo (Ipomea murucoides ), varaduz (Eysenhardthya polystachya), venadilla (Bursera fagaroides), and palo blanco (Forestiera phillyreoides ), among others (Argumedo-Espinoza et al., 2018).

The TF areas selected included: 1) "Monte Grande", coordinates $22^{\circ} 17^{\prime} 01$ " to $22^{\circ} 13^{\prime} 27^{\prime \prime} \mathrm{N}$ and $102^{\circ} 38^{\prime}$ 
$22^{\prime \prime}$ to $102^{\circ} 33^{\prime} 12^{\prime \prime} \mathrm{W}$ and altitude between 2480 and 3080 meters above sea level. This area had biological, cultural, ecotourism and environmental services use, and a surface area of 3852 hectares. 2) "Mesa del Águila y del Aserradero", with the Aserradero between the coordinates $22^{\circ} 11^{\prime} 55.5^{\prime \prime} \mathrm{N}$ and $102^{\circ} 35^{\prime} 47.6^{\prime \prime} \mathrm{W}$ and the Águila between the coordinates $22^{\circ} 12^{\prime} 1.52^{\prime \prime} \mathrm{N}$ and $102^{\circ} 35^{\prime} 11.03^{\prime \prime} \mathrm{W}$; they are separated by a ravine and are both areas of private property. In the DTF, a study area consisting of $45 \%$ of the total was selected in the "El Terrero de la Labor" property, with extreme coordinates $102^{\circ} 43^{\prime} 58.88^{\prime \prime} \mathrm{W}$ and $22^{\circ} 6{ }^{\prime} 4.78^{\prime \prime} \mathrm{N}$ and, in the extreme Southeast, $102^{\circ} 41^{\prime} 24.95^{\prime \prime} \mathrm{W}$ and $21^{\circ} 44^{\prime} 27.61^{\prime \prime} \mathrm{N}$ (Argumedo-Espinoza et al., 2018) (Fig. 1).

\section{Collection and identification of scats}

The visits were carried out in the years 2018 and 2019. Within each area in the TF and DTF, scats were collected by means of transects, using the direct search method proposed by Nova (2012), which consisted in making walking routes through the study area to locate scats by sight. The establishment of transects and scat collection were carried out using the methodology proposed by Rubalcava-Castillo et al. (2020), where each transect consisted of a central line $2 \mathrm{~km}$ long, with two parallel lines located $20 \mathrm{~m}$ on each side of the central line, and the scats were collected within the transect area. For this, 30 transects were established in each area on trails for the movement of fauna, on dirt roads, and between vegetation. The scat corresponding to each mammalian species was identified based on the Manual for Tracking the Wild Mammals of Mexico (Aranda-Sánchez, 2012). To identify the potential prey of the hypercarnivores, the guard hairs of the prey contained in the scats of the predators were identified by consulting the identification guide suggested by Monroy-Vilchis and Rubio-Rodríguez (2014).

Identification and abundance of seeds

The scats were left to dry at room temperature $\left(23^{\circ} \mathrm{C}\right)$ for 24 hours in Petri dishes, then the seeds were extracted, washed with running water, and left to dry for 24 hours for future analysis and identification. The seeds of each scat sample were quantified and then separated according to the plant species. This process was carried out using a stereoscopic microscope (Leica Microsystems, MZ6, Switzerland) to estimate the total number of seeds per scat and the richness of forest species, from which the abundance of seeds was determined by plant species, animal disperser and type of forest (temperate or tropical).

Control groups

Based on the abundance of seeds found in the scats for each plant species, a control group was established, with seeds taken from ripe fruits collected in the canopy of the TF and DTF for viability tests, SEM and germination test.

Viability test

Viability tests were carried out for the control seeds and seeds from the scats of both types of forest by means of optical densitometry analysis using an X-ray equipment (Faxitron X-Ray Corporation, Texas, USA, at 10 $\mathrm{s}$ and $26 \mathrm{kv}$ intensity), according to the technique proposed by De La Garza and Nepamuceno (1986). Densitometry analysis was performed for each individual seed from the controls and the scats of each mammal, dispersed plant species and forest type, based on the technique proposed by Rubalcava-Castillo et al. (2020), where viable seeds were distinguished from non-viable seeds by the presence of underdeveloped/incomplete embryos, empty seeds or no embryo.

Scanning electron microscopy

The measurements of the thickness of the canopy seed testas were compared against those of the seeds from the scats of the TF and DTF. For this, whole and sagittal cut seeds were used, which were coated with gold for 4 minutes in a Denton Vacuum bathing suit (JFC-1100@, JEOL LTD, Tokyo, Japan). Once prepared, the seeds were observed in the camera of a scanning electron microscope (JSM-35C@), JEOL LTD, Tokyo, Japan) (Dykstra and Reuss, 2003) in the Electron Microscopy Laboratory of the Department of Biology of the Center of Basic Sciences at the Autonomous University of Aguascalientes. To perform the analyses and 
verify the wear on the testas when the seeds passed through the digestive tracts of mammals, measurements were made at 40x, with respect to the thickness, in three parts of the testa: (1) the micropyle portion, (2) central portion, and (3) portion opposite the micropyle (Fig. 2A); three measurements were made per portion (Fig. 2B). In addition, qualitative characteristics were observed on the surfaces and interiors of the testas, such as: loss of superficial plant layers and the presence of holes and cracks in the external and internal parts of the testas.

\section{Germination test}

The scats and canopy seeds were washed in a $10 \%$ chlorine solution. Subsequently,

three washes with distilled water were carried out to eliminate excess chlorine, and finally a fungicide was added (Interguzan 30-30, Int. Química de Cobre, Mexico) at a concentration of $1.2 \mathrm{~g}$ per $100 \mathrm{ml}$. The seeds were placed in Petri dishes and immediately moistened with $4 \mathrm{ml}$ of distilled water, according to the forest seeds manual by Antonio-Bautista (2012). The samples were subjected to independent germination tests in a germination chamber (Lab Line, Imperial III, Melrose Park, IL, USA) at a controlled temperature of 25@C and a photoperiod of $12 \mathrm{~h}$ for 61 days. All dishes were monitored every two days, registering the number of germinations per sample, where those in which the radicles were visible were taken as germinated seeds (Herminio, 2003).

\section{Statistical analysis}

To analyze the contribution of each mammal in the dispersion of seeds for each plant species in the TF and DTF, the Shapiro-Wilks test was performed to determine normality; analysis of variance (ANOVA), Tukey's honest significant difference (HSD) test, as well as the Kruskall-Wallis test were also performed. For the evaluation tests of X-ray optical densitometry, testa thickness and germination, Dunnett's test was integrated to compare the data of the seeds dispersed by mammals with those of the seeds from the canopy in each plant species and type of forest. All analyses were carried out at a significance level of $95 \%$ using the Statgraphics program $(16.1,2012)$.

\section{RESULTS}

\section{Seed dispersal}

In the TF, four species of mammals associated with the dispersal of seeds were identified, finding significant differences between the abundance of seeds dispersed by these animals $\left(X^{2}=18.64, P=0.00\right)$. The gray fox was the mammal that dispersed the highest number of seeds $(66.8 \pm 68.2)$, while the coyote dispersed the least quantity of seeds $(4.0 \pm 2.7)$. It should be noted that in this forest ecosystem, the bobcat was identified as a diploendozoochoric disperser because of the presence of seeds in its scats associated with hair of the rabbit species Sylvilagus floridanus $(11 \pm 0)$ (Fig. 3A). Also, four plant species were dispersed, observing significant differences with respect to the abundance of seeds $\left(X^{2}=18.6, P=0.00\right)$, where the seeds of $A$. pungens were dispersed in the highest average abundance $(200.83 \pm 136.16)$ and those of $Y$. filifera in the least abundance $(10.4 \pm 13.4)$. Arbutus $s p$. presented a good abundance despite being dispersed only by the ringtail (Fig. 3B).

Four dispersing mammals were found in the DTF - the gray fox and the ringtail, as in the TF, as well as the coati and the badger - but no diploendozoochoric mammals were found. Significant differences were found in the abundance of seeds dispersed by the animals $\left(F_{3,27}=4.93, P=0.00\right)$, where the coati was the mammal that dispersed the highest abundance of seeds $(8639 \pm 12203)$ and the badger dispersed the least amount $(7.0 \pm 0.0)$ (Fig. 3C). Thus, the DTF presented a greater abundance and richness of dispersed species, as five plant species were dispersed. Regarding the abundance of seeds per plant species, no significant differences were observed $\left(P<0.05, F_{4,26}=1.28, P=0.30\right)$, despite the existence of a large difference in abundance between the dispersion of $M$. geometrizans ( $2680 \pm 4423$ ), the species with the highest average abundance, and P. laevigata $(20.8 \pm 22.3)$, the one with the lowest abundance (Fig. 3D).

Viability 
Five species of plants were selected for analysis based on the abundance of seeds found in the scats; for the TF, seeds of Arbutus sp.,A. pungens and Juniperus sp . were used, while for the DTF, seeds of $F$. phillyreoides and M. geometrizans were used. These plant species were dispersed in the scats of these five mammals, gray fox, coyote, ringtail, bobcat, and coati, in the order given above. The contribution presented by each mammal in maintaining viability was different, showing statistical differences in the coyote $(P<$ $\left.0.05, F_{1,9}=8.60, P=0.01\right)$ of $67.0 \%$ in both species of dispersed plants, and in the bobcat $(P<0.05$, $\left.F_{1,3}=10.76, P=0.04\right)$ of $54.5 \%$, both the lowest percentages, while the other mammals presented similar percentages to the controls. No statistical differences were found when comparing viability between all forest species of the TF $(P=0.63)$ and the DTF $(P=0.59)$ (Table 1$)$.

Particularly, in seeds of Arbutus sp . in the TF, no significant differences were found, with the ringtail reducing the average percentage of viability of these seeds $(70.0 \pm 19.8)$ compared to those of the canopy $(86.0 \pm 7.7)$. On the other hand, for $A$. pungens, significant differences $(P<0.05)$ were found for the seeds dispersed by the gray fox $(91.6 \pm 6.1)$, which presented the highest average percentage of viability with respect to the canopy $(76.0 \pm 5.7)$. In Juniperus $s p$., no statistical differences were found; however, the gray fox $(82.6 \pm 12.4)$, again, managed to maintain viability at a higher percentage than the canopy $(77.0 \pm 6.0)$, while practically half of the seeds dispersed by the bobcat were viable. In the DTF, no significant differences were recorded for the seeds of $F$. phillyreoides ; however, the gray fox $(92.0 \pm 11.3)$ managed to maintain a higher percentage of viability than the canopy $(79.0 \pm 6.8)$. Likewise, for $M$. geometrizans, no significant differences were observed, although most of the mammals managed to maintain viability with respect to the canopy $(87.0 \pm 3.8)$, with the exception of the ringtail $(75.3 \pm 14.6)$, which presented a lower percentage (Table 1).

In the seeds of Juniperus $s p$. from the TF, changes in the testas were observed by X-ray, suggesting changes in the viability of the seeds due to passage through the digestive tracts of the gray fox, coyote, ringtail and bobcat, but without apparent damage to the seed embryos (Fig. 4).

The thickness of the testas of the seeds of Juniperus sp. from TF and F. phillyreoides from DTF was analyzed. Significant differences were found, according to the results of the Tukey test when verifying whether the thickness of the testas were different $\left(P<0.05, F_{4.40}=4.47, P=0.00\right)$, due to the fact that the seeds dispersed by all the mammals had larger average thicknesses than those of canopy (731 \pm 238$)$, particularly those dispersed by the ringtail $(1480 \pm 717)$ and the bobcat $(1181 \pm 372)$. While for the DTF the thicknesses were thinner compared to the seeds of the TF, there were, nevertheless, significant differences between the seeds dispersed by the mammals and those of the canopy $\left(F_{2,20}=4.30, P=0.02\right)$, and as in the TF, the seeds dispersed by the ringtail had the highest average thickness $(281 \pm 50.6)$ with respect to the canopy $(215 \pm 42.3)$ (Fig. 5). This was also corroborated by the results of the Dunnett's test, which verified that, for both TF and DTF, the ringtail presented the greatest significant difference with respect to the other dispersers and the canopy, showing that this mammal was associated with thicker testas.

For the canopy from the TF, the testa of the Juniperus $s p$. seed had a protective external vegetal fibrous layer (Fig. 6A). This layer was removed when the seed passed through the digestive tract of mammals such as the bobcat (Fig. 6B). The layer also presented wear or removal when the seed passed through the digestive tract of the gray fox (Fig. 6C), and it was possible to appreciate the formation of cracks caused by passage through the tract of the ringtail (Fig. 6D), which could facilitate the entry of water and favor germination.

In the DTF, the seed of $F$. phillyreoides did not have this protective layer, but only a line pattern on the surface (Fig. 7A). There was a change in the pattern of the lines when it passed through the digestive tract of the gray fox, resulting in cracks and holes (Fig. 7B) but with no damage to the internal parts, thus the endosperm and the embryo remained in good condition (Fig. 7C). In the seeds obtained from the ringtail scats, large openings were observed on the surfaces (Fig. 7D), possibly facilitating the entry of water and oxygen through the testas.

Germination

The five plant species with their respective scatterers selected for the X-ray analysis were also used for the 
germination test. The seeds obtained from the coyote and bobcat scats did not germinate, so the analysis was based on the three remaining mammal species. For these species, the Tukey and Dunnet tests yielded no significant differences in germination percentages for the gray fox $(P=0.94)$, ringtail $(P=0.54)$ and coati $(P=0.56)$, since each mammal presented a similar percentage to the controls. Still, these animals managed to promote germination. In the same way, there were no statistical differences when comparing the percentages between the two types of forest (Table 2).

When performing the analysis for each plant species, no significance was found for Arbutus $s p$. in the TF $\left(F_{1,4}=1.58, P=0.27\right)$, since the germination percentages of the control $(70.0 \pm 3.3)$ and ringtail $(62.2 \pm$ 10.2 ) were similar. For $A$. pungens, only the gray fox managed to germinate seeds in a very low percentage $(1.1 \pm 1.9)$, as in the canopy $(2.2 \pm 1.9)$. Therefore, there were no statistical differences $\left(F_{2,4}=0.57, P=\right.$ 0.60). Finally, in Juniperus sp., it was observed that the percentages of the gray fox $(12.2 \pm 8.4)$ and the ringtail $(17.5 \pm 10.6)$ were higher than that of the control $(5.6 \pm 1.9)$, but no significant differences $\left(F_{4,5}\right.$ $=1.79, P=0.27)$ were found. In the DTF, for $F$. phillyreoides, significant differences were found between the germination percentages $\left(F_{2,6}=14.16, P=0.00\right)$, with a higher average percentage observed for the canopy seeds $(73.3 \pm 3.3)$ than for the dispersers, particularly the ringtail, where significant differences were presented for the Tukey and Dunnet tests, as the seeds dispersed by the ringtail presented the lowest germination percentages $(27.8 \pm 5.1)$. On the other hand, for $M$. geometrizans, there were no significant differences between the average germination of the control and those of the seeds from the animals $\left(F_{3,8}=\right.$ $0.65, P=0.60)$, but it was possible to verify from the percentages that all the mammals, especially the gray fox $(58.9 \pm 20.4)$, managed to improve germination with respect to the canopy (44.4 \pm 6.9$)$ (Table 2).

\section{DISCUSSION}

\section{Seed dispersal}

In the TF, the gray fox was the most efficient mammal because $100 \%$ of its scats contained seeds of some plant species, showing that this carnivore can adapt its eating habits by consuming fruits as an important resource in its diet (Valkenburgh , 1996). However, it is possible to find differences in seed dispersal, depending on the species of fox and species of dispersing plant, as explained by Bravo, Berrondo \& Cueto (2019), who found that only $46 \%$ of the scats of the Andean fox (Lycalopex culpaeus) contained seeds of Prunus cerasus andMalus domestica. On the contrary, the coyote dispersed a very low quantity of seeds (4), similar to the results obtained by Roehm and Moran (2013), who reported an average of 16 Diospyros virginianaseeds in their scats. This is because coyote diet is mainly composed of rodents and hares, and the plant elements are only a complement (Martínez-Vázquez, González-Monroy, \& Díaz-Díaz, 2010). So, in our case, the role of this mammal in seed dispersal in the TF was limited by its preferentially opportunistic diet. It is important to mention the role of the bobcat as a diploendozoochoric seed disperser (Hämäläinen et al., 2017), since $J$. deppeana seeds were found in its scats, endorsing the results of Rubalcava-Castillo et al. (2020), who reported that this feline dispersed this plant species by disseminating an average of 0.8 seeds, while our results reported an increase in abundance with 11 seeds. These results reinforce those of other studies that have demonstrated the diploendozoochory of some of these carnivores, such as the study carried out by Kurek \& Holeksa (2015) on the red fox and marten, and that of Sarasola et al. (2016), who demonstrated the dispersal of seeds by cougar, another feline that feeds strictly on carnivorous diets. For this reason, it is important to begin to consider hypercarnivores, such as the bobcat, as an important part of the guild of seed dispersers and participants in the regeneration of forest ecosystems.

Plants dispersed by mammals have a wide distribution in the TF of the Sierra Fría (Díaz-Núnez et al., 2016), as is the case of $A$. pungens, which the mammals under study managed to disperse with the highest average abundance. This is similar to the finding reported by Rubalcava-Castillo et al. (2020), who obtained an average of 212 seeds for this same plant species. Matías et al. (2010) reported an average of 28 seeds for the species A. uva-ursi dispersed by red fox (Vulpes vulpes), stone marten (Martes foina), and wild boar (Sus scrofa). Arbutus sp. showed the second highest average abundance despite only being disseminated by the ringtail. Therefore, it can be said that this carnivore feeds selectively on this plant species (Koike et al., 2008), and the dispersal of this plant species could be attributed only to the ringtail. Although a 
relatively low average abundance was found for Juniperus sp., the average number of seeds reported in this study (46.8) is higher than the 23.6 dispersed seeds reported by Rubalcava-Castillo et al. (2020). Therefore, it is important for future long-term studies to allow us to understand the variables that intervene in the abundance of dispersed seeds over the years.

On the other hand, in the DTF, the mammals under study are primarily involved in the regeneration process through seed dispersal. For example, the coati dispersed the largest number of seeds, about 8600, in this forest, a larger quantity than the 322 seeds of Ficus obtusifolia dispersed by the same mammal in the study carried out by Alves-Costa \& Eterovick (2007) in Brazil. Likewise, the gray fox and the ringtail also play an important role in the dispersal of seeds, disseminating a large number from a variety of plant species. Thus, the families Procyonidae and Canidae, to which the coati, the ringtail and the gray fox belong, play a crucial role as alternative dispersers in forest landscapes such as DTF (Alves-Costa \& Eterovick, 2007).

Thus, the abundance of seeds dispersed in the DTF was much higher than in the TF, since the fruits of certain plant species in DTF contain large quantities of seeds, and through endozoochory the vertebrates can disperse 70 to $90 \%$ of woody plant species in tropical forests (Fleming et al. 1987). In the same way, the richness of plant species found in the DTF was greater than in the TF, but not high, since only five species were found. In contrast, Zarco-Mendoza, Ríos, \& Godínez-Álvarez (2018) found 18 species dispersed by carnivores and Alves-Costa \& Eterovick (2007) found 53 species in the DTF, which suggests that carnivores in our tropical forest study area selectively feed on few plant species (Koike et al., 2008), despite the great richness of species in the forest (Argumedo-Espinoza et al., 2018). In particular, the species with the highest abundance of dispersed seeds was M. geometrizans, which Pérez-Villafaña \& Valiente-Banuet (2009) indicated is mainly dispersed by birds and, to a lesser extent, by terrestrial mammals such as foxes and ringtails. However, our results show the coati, in addition to these mammals, as the main disperser and disseminator of a large number of seeds. Therefore, due to the contribution of the coati as a disperser, M. geometrizans showed the highest abundance in this study with an average of 2680 dispersed seeds, a quantity much higher than the 163 dispersed seeds obtained by Zarco-Mendoza, Ríos, \& Godínez-Álvarez (2018).

\section{Viability}

The viability of seeds is essential for their germination, survival, and establishment. In the TF, the gray fox managed to keep almost all of the seeds of $A$. pungens viable, showing that it has the ability to keep the seeds alive, a result that is in contrast to that reported by Rubalcava-Castillo et al. (2020). This result indicates that this mammal affects the viability of this plant, and further suggests that the alterations or damage that the seeds may receive from the canopy and in the animal's tract may differ depending on the year and the study area. However, it is important to carry out studies to explain how the year and area affect the damage to the seeds for a better understanding of the functions of these animals. In the same way, Rubalcava-Castillo et al. (2020) reported that the viability in the ringtail for A. pungens was $69 \%$, which is practically similar to that obtained in the present study (70\%), so it is clear that the ringtail also manages to maintain a large percentage of viable seeds. Regarding Arbutus sp ., which belongs to the same family (Ericaceae) as A. pungens, we also found that the ringtail, being its only disperser, could keep most of the seeds viable, proving to be a mammal ideal for the dispersal of this species of plant. It was observed that the gray fox and ringtail maintained a high viability for Juniperus $s p$. with respect to the canopy, with the dispersed seeds remaining unchanged in their testas, which confirms the importance of these animal species in the endozoochory of this forest species.

Diploendozoochory had a reduced effect on the viability of seeds dispersed by the bobcat compared to the viability of seeds dispersed by the other mammals. Conversely, Nogales et al. (2015), studied the effect of diploendozoochory on the viability of $J$. turbinata seeds after passage through the tracts of the Galliota lizard and its predator, the feline of the Felis genus, and found that the original viability was fairly maintained. The decrease in viability of the seeds associated with the bobcat could be due to the fact that most of the testas presented cracks and structural alterations possibly caused by the high retention times in the digestive tracts of the carnivores (Hämäläinen et al., 2017). However, the embryos remained intact and apparently alive. Therefore, the alteration in the testas was not necessarily negative for the seeds, but could be an 
advantage, since water, oxygen and light could easily enter the thick testa through the cracks.

The gray fox was the mammal that maintained the highest viability for the seeds of $F$. phillyreoides in the DTF. This result somewhat coincides with that of Campos \& Ojeda (1997), who found that the gray fox was the wild mammal that maintained the highest viability for $P$. flexuosa seeds. This shows that this animal can maintain the viability of forest species in different types of forest. For $M$. geometrizans, the coati managed to maintain viability for almost all of the seeds that passed through its tracts, and this finding is similar to that observed by Alves-Costa \& Eterovick (2007), who reported that this mammal managed to keep the seeds viable in its scats. This establishes the role and importance of the coati as a mammal able to disperse a high quantity of $M$. geometrizans seeds while maintaining their viability.

We see that most of the animals under study maintained the viability of the seeds dispersed in both types of forest, improving dispersal success by selecting high quality seeds and fruits (Benítez-Malvido et al., 2016). It is possible that mammals have some mechanisms for selecting fruits to ingest those that are in good condition and avoid those with some damage, because in our results, there were percentages of viability higher than those of the canopy for most of the animals in both forests. However, there is the need for more studies that will follow this line of research to corroborate the above.

The result of the dispersal process through the animals could be aided by the seeds coming in contact with the acids of the digestive tracts, which cause changes in the internal and external structures of the testas, generally decreasing their thickness (Traveset et al. 2001; Nogales et al. 2007). However, our SEM results showed that the testas in seeds dispersed by the mammals in both forests did not cause a decrease in the thickness, but the opposite. An increase in the thickness of the testas of the seeds of Juniperus $s p$. and F. phillyreoideswas achieved in all the animal species, especially in the ringtail, and even in the diploendozoochory due to the bobcat. On the contrary, Nogales et al. (2015) observed a decrease in the thickness of the testas of the seeds of Plocama pendula and Rubia fruticosadispersed by a lizard of the genus Galliota and a feline of the genus Felis through diploendozoochory. In our case, the increase in thickness might be due to the prolonged time that the seeds spent in the tracts, and absorption of the liquids in the intestines by the seeds could have occurred and thus caused their swelling. However, it was not possible to demonstrate this in the current study, and subsequent studies may want to describe this absorption of liquids by seed coatings caused by the passage of the seeds through the tracts of mammals.

It was also possible to observe, through SEM, the removal of the superficial vegetal layers of the Juniperus $s p$. seeds, as can be seen in Figure 6. This removal probably benefitted the seed since the first obstacle to the entry of essential elements (water, light, oxygen) for germination was thus eliminated. This finding coincides with that of Costea et al. (2016), who observed that seeds of the genus Cuscuta that passed through the digestive tracts of aquatic birds were also able to shed their surface layers. For F. phillyreoidesseeds, it was possible to observe cracks in their testas caused by their passage through the digestive tracts of all their animal dispersers, an observation that coincides with that of Schaumann \& Heinken (2002), who reported cracks of the species Vaccinium myrtillus dispersed by the mammal $M$. foina . Furthermore, through SEM it was also possible to observe cracks between the internal and external structure of the testa of Juniperus $s p$., which caused fragmentation in the testa (Costea et al., 2016) and enhanced the permeability of water and other elements. Given these findings, we can conclude that the mammals under study, in addition to their roles as dispersers, are crucial for the retention of seed viability and the production of holes and cracks in the seeds from different forest ecosystems that are beneficial to their germination.

\section{Germination}

For the TF seeds, endozoochory enhanced germination, as in the case of Arbutus sp ., where although the action of the ringtail did not lead to a higher germination rate than that of the control, the percentages were very similar, which suggests that the passage of seeds of this plant species through the tract of this mammal does not affect germination but enables endozoochory. Since the seeds of this genus need to be freed from the pulp of the fruit to germinate and be dispersed by animals, it can be said that endozoochory enables germination (Narbona, Arista, \& Ortiz, 2003). For the seeds of A. pungens andJuniperus sp ., the 
mammals also managed to promote germination in low percentages, although higher than those reported by Rubalcava et al. (2020), who observed zero germination rate for A. pungens . For J. deppeana, Rubalcava et al. (2020) obtained germination rates of $0.61,8$ and $6.7 \%$ for seeds acted on by the gray fox, coyote and bobcat respectively, while we found higher percentages for the gray fox $(12.2 \%)$ and ringtail (17.5\%), which might be an indication of how alterations to the testas of the Juniperus sp . seeds observed by SEM could have caused increase in germination rates.

Diploendozoochory involving the bobcat failed to promote germination of the Juniperus $s p$. seeds, since despite being a disperser, germination was not achieved because the few seeds found in its scats were of very small sizes and still at an early maturation stage. Thus, this fact possibly verifies that some vertebrates with strong enzymatic digestion, such as felines, greatly damage the seeds (Nogales et al., 2015). However, Rubalcava-Castillo et al. (2020), achieved the germination of the seeds of Juniperus sp. found in bobcat scats. Due to this variable rates of germination and the high variation in the viability of the seeds of some Juniperus species (Rumeu et al. 2011), it is difficult to evaluate the effect of felines on their germination (Nogales et al., 2015). This is because the high latency recorded must be integrated with the low germination described for many Juniperus species (Adams 2008; Rumeu et al. 2009).

The germination rates of seeds of the DTF from the controls and the scats were higher than that of the TF, because the tropical seeds under study did not present thick testas that hindered the passage of elements for germination. In the case of $F$. phillyreoides, the highest percentages were presented by the control seeds. Despite this, the mammals managed to promote germination, especially the gray fox, which seeds obtained from its scats presented the highest percentage for this plant of all the animals. Campos \& Ojeda (1997) suggested that for $P$. flexuosa seeds, the gray fox could maintain viability without improving germination, compared to the controls, and, therefore, the intestinal passage could have positive or negative effects on germination (Cypher \& Cypher, 1999). Thus, the adaptive importance of these mammals to trees such as $F$. phillyreoides is related to dispersal (Peguero \& Espelta, 2014), although they can also be scarifiers of this plant species, which benefits from this pre-germinative treatment that removes the endocarps (MartínezCalderón et al., 2020) and enhances germination. For M. geometrizans, seeds found in the scats of all the mammals presented germination rates greater than that of the control, confirming the role of these animals as dispersers and scarifiers for this plant species. But this result differs from that of Zarco-Mendoza, Ríos, \& Godínez-Álvarez (2018), who reported that the dispersed seeds by carnivores of this same plant species barely managed to reach a germination rate of $0.27 \%$. In our study, the gray fox was the mammal with the biggest effect on the germination of these seeds, presenting the highest percentage, a result that coincides with that of Traba et al. (2006) to an extent, who also found that the red fox had the highest influence on the germination of the seeds of Celtis australis . For the above and recapitulating, the gray fox in the tropical forest is positioned as the species of mammal whose action on the seeds of $F$. phillyreoides and $M$. geometrizans has the biggest positive effect on their germination.

\section{Conclusions}

The results of the present study suggest that in the temperate forest and in the dry tropical forest, carnivores take advantage of the seasonal abundance of fruits to complement their diet, giving rise to a process of dispersal of scats with viable seeds that germinate, extend and reinforce the structure forest. This ecological dispersal process is controlled by the abundance and richness of seeds, as well as by the adaptive characteristics of the seed coat to resist digestive scarification without affecting their viability. In this study, the abundant and efficient participation of the gray fox and ringtail as dispersers of Arctostaphylos pungens in the temperate forest andMyrtillocactus geometrizans in the dry tropical forest was highlighted. Evidence was also found for seed dispersal by the rabbit-fed bobcat Sylvilagus floridanus .

\section{REFERENCES}

Adams, R. P. (2008). Junipers of the world: the genus Juniperus . Trafford Publishing, Vancouver.

Alves-Costa, C. P., \& Eterovick, P. C. (2007). Seed dispersal services by coatis (Nasua nasua, Procyonidae) and their redundancy with other frugivores in southeastern Brazil. Acta Oecologica , 32(1), 77- 
92.https://doi.org/https://doi.org/10.1016/j.actao.2007.03.001.

Antonio-Bautista, A. (2012). Manual de Ensayos de Semillas Forestales Recopilación de Información. Coahuila. ISBN-978-607-95357.

Aranda-Sánchez, J. M. (2012). Manual para el Rastreo de Mamíferos Silvestres de México (C. N. p. e. C. y. U. d. l. B. (CONABIO) Ed. Primera ed.). México, D.F. Argumedo-Espinoza, J., Sosa Ramírez, J., DíazNúñez, V., Pérez-Salicrup, D. R., \& Siqueiros Delgado, M. E. (2018). Diversity, Distribution, and Abundance of Woody Plants in a Dry Tropical Forest: Recommendations for Its Management BT - Mexican Natural Resources Management and Biodiversity Conservation: Recent Case Studies. In A. Ortega-Rubio (Ed.) (pp. 479-500). Cham: Springer International Publishing. https://doi.org/10.1007/978-3-319-90584-6_21.

Benítez-Malvido, J., Zermeño-Hernández, I., González-DiPierro, A. M., Lombera, R., \& Estrada, A. (2016). Frugivore choice and escape from pre-dispersal seed predators: the case of Dialium guianense and two sympatric primate species in southern Mexico. Plant Ecol . 217, 923e933.

Bravo, S. P., Berrondo, M. O., \& Cueto, V. R. (2019). Are small abandoned plantations a threat for protected areas in Andean forests? The potential invasion of non-native cultivated species. Acta Oecologica, 95, 128-134. https://doi.org/https://doi.org/10.1016/j.actao.2018.11.002.

Campos, C., Peco, B., Campos, V., Malo, J., Giannoni, S., \& Cardona, F. (2008). Endozoochory by native and exotic herbivores in dry areas: Consequences for germination and survival of Prosopis seeds. Seed Science Research , 18 , 91-100. https://doi.org/10.1017/S0960258508940344.

Campos, C. M., \& Ojeda, R. A. (1997). Dispersal and germination of Prosopis flexuosa (Fabaceae) seeds by desert mammals in Argentina. Journal of Arid Environments , 35(4), 707-714. https://doi.org/https://doi.org/10.1006/jare.1996.0196.

Chakravarthy, D., \& Ratnam, J. (2015). Seed Dispersal of Vitex Glabrata and Prunus Ceylanica by Civets (Viverridae) in Pakke Tiger Reserve, North-East India: Spatial Patterns and Post-Dispersal Seed Fates. Tropical Conservation Science , 8 , 491-504. https://doi.org/10.1177/194008291500800213.

Costea, M., Stefanović, S., García, M. A., De La Cruz, S., Casazza, M. L., \& Green, A. J. (2016). Waterfowl endozoochory: An overlooked long-distance dispersal mode for Cuscuta (dodder). American Journal of Botany , 103(5), 957-962.https://doi.org/10.3732/ajb.150050\%.

Cypher, B. y Cypher, E. (1999). Germination rates of tree seeds ingested by coyotes and raccoons. The American Midland Naturalist., 71-76. doi:http://dx.doi.org/10.1674/00030031(1999)142[0071:GROTSI]2.0.CO;2.

D'hondt, B., Vansteenbrugge, L., Van Den Berge, K., Bastiaens, J., \& Hoffmann, M. (2011). Scat analysis reveals a wide set of plant species to be potentially dispersed by foxes. Plant Ecology and Evolution . Retrieved from https://www.ingentaconnect.com/content/botbel/plecevo/2011/00000144/00000001/art00010.

De la Garza, L.P. y Nepamuceno, M. F. (1986). Análisis radiográfico de semillas forestales en México. Revista ciencia forestal , 1-14 pp.

Díaz-Núñez, V, Sosa-Ramirez J, Pérez-Salicrup. D. R. (2016). Vegetation patch dynamics and tree diversity in a diverse conifer and oak forest in central Mexico. Botanical Sciences , 94(2), 12. https://doi.org/http://dx.doi.org/10.17129/botsci.284.

Dykstra, M. J, and Reuss L. (2003). Biological Electron Microscopy: Theory, Techniques and Troubleshooting. Kluwer Academic/Plenum, 2003. New York. 534 p.

Fleming, T. H., R. Breitwisch, and G. H. Whitesides. (1987). Patterns of tropical vertebrate frugivore diversity. Annu. Rev. Ecol. Syst . 18: 91-109.

Godínez-Alvarez, H., Rojas-Martínez, A., \& Zarco-Mendoza, P. (2007). Dispersión de semillas por mamíferos: el caso del Valle de Tehuacán, una zona árida del centro de México. In G. Sánchez-Rojas \& A. Rojas-Martínez 
(Eds.), Tópicos en sistemática, biogeografía, ecología y conservación de mamíferos (pp. 135-149). México: Universidad Autónoma del Estado de Hidalgo.

Haarmeyer, D. H., Bösing, B. M., Schmiedel, U., \& Dengler, J. (2010). The role of domestic herbivores in endozoochorous plant dispersal in the arid Knersvlakte, South Africa. South African Journal of Botany ,76 (2), 359-364. https://doi.org/https://doi.org/10.1016/j.sajb.2009.12.001.

Hämäläinen, A., K. Broadley, A. Droghini, J. A. Haines, C. T. Lamb, S. Boutin, and S. Gilbert. (2017). The ecological significance of secondary seed dispersal by carnivores. Ecosphere, 8(2). doi:e01685. $10.1002 / \operatorname{ecs} 2.1685$.

Herminio, R. F. (2003). Estado del conocimiento de Juniperus deppeana Steud. Tesis de Ingeniería. Universidad autónoma Chapingo. $92 \mathrm{pp}$.

Howe, H., \& Miriti, M. (2000). No question: Seed dispersal matters. Trends in Ecology \& Evolution , 15 , 434-436. https://doi.org/10.1016/S0169-5347(00)01965-0.

Koike, S., Morimoto, H., Goto, Y., Kozakai, C., \& Yamazaki, K. (2008). Frugivory of carnivores and seed dispersal of fleshy fruits in cool-temperate deciduous forests. Journal of Forest Research , 13(4), 215222.https://doi.org/10.1007/s10310-008-0069-5.

Kurek, P., \& Holeksa, J. (2015). Grains in the diets of medium-sized carnivores -a case of diplochory? Polish Journal of Ecology , 63, 286-290.https://doi.org/10.3161/15052249PJE2015.63.2.012.

Martínez-Calderón, V., Sosa-Ramírez, J., González, J., Mendieta-Vázquez, A., \& Sandoval Ortega, M. H. (2020). Propagation of Forestiera phillyreoides : A potential species for restoration in north-central Mexico. Madera y Bosques , 26, e2622052. https://doi.org/10.21829/myb.2020.2622052.

Martínez-Vázquez, J., María González-Monroy, R., \& Díaz-Díaz, D. (2010). Hábitos alimentarios del Coyote en el parque nacional Pico de Orizaba. Therya , 1, 145-154.https://doi.org/10.12933/therya-10-4.

Matías, L., Zamora, R., Mendoza, I., \& Hódar, J. A. (2010). Seed Dispersal Patterns by Large Frugivorous Mammals in a Degraded Mosaic Landscape. Restoration Ecology , 18(5), 619627.https://doi.org/10.1111/j.1526-100X.2008.00475.x.

Monroy-vilchis, O., \& Rubio Rodríguez, R. (2014). Guía de identificación de mamiferos terrestres del Estado de México, a través del pelo de guardia (1). México: Universidad Autónoma del estado de México. 115 pp.

Narbona, E., Arista, M., \& Ortiz, P. (2003). Germinación de las semillas del madroño (Arbutus Unedo L., Ericaceae). Acta Botánica Malacitana , ISSN 0210-9506, No 28, 2003, Pags. 73-78, 28.https://doi.org/10.24310/abm.v28i0.7267.

Nogales M., Padilla D. P., Nieves C., Illera J. C., \& Traveset A. (2007). Secondary seed dispersal systems, frugivorous lizards and predatory birds in insular volcanic badlands. J Ecol , 95:1394-1403.

Nogales, M., Castañeda, I., López-Darias, M., Medina, F. M., \& Bonnaud, E. (2015). The unnoticed effect of a top predator on complex mutualistic ecological interactions. Biological Invasions , 17(6), 16551665.https://doi.org/10.1007/s10530-014-0823-x.

Nova J. S. (2012). The Wildlife Techniques Manual: Volume 1: Research. Volume 2: Management. Ed The Johns Hopkins University Press. 7ma edición. Baltimore, Maryland, USA. 686 y 414 pp.

Peco, B., Lopez-Merino, L., \& Alvir, M. R. (2006). Survival and germination of Mediterranean grassland species after simulated sheep ingestion: ecological correlates with seed traits. Acta Oecologica , 30 , 269275.https://doi.org/10.1016/j.actao.2006.05.004.

Peguero, G., \& Espelta, J. M. (2014). Endozoochory and Fire as Germination Triggers in Neotropical Dry Forests: an Experimental Test.Biotropica , 46(1), 83-89.https://doi.org/10.1111/btp.12076. 
Pérez-Villafaña, M., \& Valiente-Banuet, A. (2009). Effectiveness of Dispersal of an Ornithocorous Cactus Myrtillocactus geometrizans (Cactaceae) in a Patchy Environment. Open Biol. J. , 2.https://doi.org/10.2174/1874196700902010101.

Roehm, K., \& Moran, M. D. (2013). Is the Coyote (Canis latrans) a Potential Seed Disperser for the American Persimmon (Diospyros virginiana)? The American Midland Naturalist , 169(2), 416421.https://doi.org/10.1674/0003-0031-169.2.416.

Rubalcava-Castillo, F. A., Sosa-Ramírez, J., Luna-Ruíz, J. J., Valdivia-Flores, A. G., Díaz-Núñez, V., \& Íniguez-Dávalos, L. I. (2020). Endozoochorous dispersal of forest seeds by carnivorous mammals in Sierra Fría, Aguascalientes, Mexico. Ecology and Evolution .https://doi.org/10.1002/ece3.6113.

Rumeu, B., Elias, R. B., Padilla, D. P., Melo, C., \& Nogales, M. (2011). Differential seed dispersal systems of endemic junipers in two oceanic Macaronesian archipelagos: the influence of biogeographic and biological characteristics. Plant Ecol, 212:911-921.

Rzedowski, J. (1978). La vegetación de México. México, D.F.: Limusa. Sarasola, J. H., Zanón-Martínez, J. I., Costán, A. S., \& Ripple, W. J. (2016). Hypercarnivorous apex predator could provide ecosystem services by dispersing seeds. Scientific Reports, 6, 1-6.https://doi.org/10.1038/srep19647.

Schaumann, F., \& Heinken, T. (2002). Endozoochorous seed dispersal by martens (Martes foina, M. martes) in two woodland habitats.Flora - Morphology, Distribution, Functional Ecology of Plants , 197(5), 370378.https://doi.org/https://doi.org/10.1078/0367-2530-00053.

Schupp, E. W., Jordano, P., \& Gómez, J. M. (2010). Seed dispersal effectiveness revisited: a conceptual review. New Phytologist ,188 (2), 333-353.https://doi.org/10.1111/j.1469-8137.2010.03402.x.

SEDESO. (1995). Programa Integral de Manejo de la Zona Sujeta a Conservación Ecológica Sierra Fría. Aguascalientes: SEDESO. Sosa-Ramírez, J. (1998). Agua y sustentabilidad en Aguascalientes Tres ensayos. Aguascalientes: Centro de Investigaciones y estudios Multidisciplinarios de Aguascalientes (CIEMA).

Sosa-Ramírez, J., V., Díaz-Núñez y A., Ponce-Montoya. (2015). Diversidad y Productividad del Estrato Herbáceo en una Sabana de la Sierra Fría, Aguascalientes. Áreas Naturales Protegidas Scripta , 1 (2): 51-66 pp. doi: 10.18242/ANPScripta.2015.01.01.02.0003.

Stoner, K. E., Riba-Hernández, P., Vulinec, K., \& Lambert, J. E. (2007). The Role of Mammals in Creating and Modifying Seedshadows in Tropical Forests and Some Possible Consequences of Their Elimination.Biotropica , 39 (3), 316-327.https://doi.org/10.1111/j.1744-7429.2007.00292.x.

Traba, J., Arrieta, S., Jesús, H., \& Cristina, C. (2006). Red fox (Vulpes vulpes L.) favour seed dispersal, germination and seedling survival of Mediterranean Hackberry (Celtis australisL.). Acta Oecologica , 30, 39-45.https://doi.org/10.1016/j.actao.2006.01.004.

Traveset A., Riera N., \& Mas R. E. (2001). Passage through bird gut causes interespecific differences in seed germination characteristics. Funct Ecol , 15:669-675.

Traveset, A., Robertson, A.W., Rodríguez-Pérez, J. (2007). A review on the role of endozoochory in seed germination. In: Dennis, A.J., Green, R.J., Schupp, E.W., Westcott, D.A. (Eds.), Seed dispersal: theory and its application in a changing world. CABI Publishing, Wallingford, pp. 78-103.

Varela, O., \& Bucher, E. H. (2006). Passage time, viability, and germination of seeds ingested by foxes. Journal of Arid Environments , 67 , 566-578.https://doi.org/10.1016/j.jaridenv.2006.03.013.

Valkenburgh BV (1996) Carnivore dental adaptations and diets: a study of trophic diversity within guilds. In: Gittleman JL (ed) Carnivore behavior, ecology, and evolution, vol 1. Cornell University Press, New York, pp 410-436.

Venier, P., Carrizo García, C., Cabido, M., \& Funes, G. (2012). Survival and germination of three hardseeded Acacia species after simulated cattle ingestion: The importance of the seed coat structure.South 
African Journal of Botany, 79 , 19-24.https://doi.org/https://doi.org/10.1016/j.sajb.2011.11.005.

Zarco-Mendoza, P., Ríos, L., \& Godínez-Álvarez, H. (2018). Dispersal and germination of seeds ingested by carnivores in the Zapotitlan de las Salinas Valley, Mexico. Polibotánica , 139147.https://doi.org/10.18387/polibotanica.46.7.

Zhou, Y.-B., Zhang, L., Kaneko, Y., Newman, C., \& Wang, X.-M. (2008). Frugivory and seed dispersal by a small carnivore, the Chinese ferret-badger, Melogale moschata, in a fragmented subtropical forest of central China. Forest Ecology and Management, 255 , 1595-1603.https://doi.org/10.1016/j.foreco.2007.11.018.

Table 1 Average viability percentages $(x \pm S D)$ from X-ray optical densitometry of seeds of Arbutus $s p$ ., Arctostaphylos pungens and Juniperus sp ., with their respective animal dispersers, in the temperate forest; and of seeds of Forestiera phillyreoides and Myrtillocactus geometrizans, with their respective animal dispersers, in the dry tropical forest (both forests are located at the Sierra Fría ANP, Aguascalientes, Mexico).

\begin{tabular}{|c|c|c|c|c|c|c|c|c|}
\hline $\begin{array}{l}\text { Disperser } \\
\text { species } \\
\text { (DS) }\end{array}$ & Forest & $\begin{array}{l}\text { Seed } \\
\text { species } \\
(\mathrm{SS})\end{array}$ & $\begin{array}{l}\text { Seeds } \\
(\mathrm{N})\end{array}$ & $\begin{array}{l}\text { Viability } \\
\text { P-value }\end{array}$ & $\begin{array}{l}\text { Viability } \\
\text { P-value }\end{array}$ & $\begin{array}{l}\text { Viability } \\
\text { P-value }\end{array}$ & $\begin{array}{l}\text { Viability } \\
\text { P-value }\end{array}$ & \\
\hline & & & & $(\%)$ & $\mathrm{DS} \times \mathrm{C}$ & $\begin{array}{l}\text { SS } x \\
\text { DS }\end{array}$ & $\operatorname{Te} \times \operatorname{Tr}$ & Te $\mathrm{x} T$ \\
\hline \multirow{5}{*}{$\begin{array}{l}\text { Canopy } \\
\text { (control } \\
\text { C) }\end{array}$} & $\begin{array}{l}\text { Temperate } \\
(\mathrm{Te})\end{array}$ & $\begin{array}{l}\text { Arbutus } \\
\text { sp. }\end{array}$ & 90 & $\begin{array}{l}86.0 \pm \\
7.7\end{array}$ & & & 0.63 & 0.63 \\
\hline & & $\begin{array}{l}\text { A. } \\
\text { pungens }\end{array}$ & 90 & $\begin{array}{l}76.0 \pm \\
5.7\end{array}$ & & & & \\
\hline & & $\begin{array}{l}\text { Juniperus } \\
\text { sp. }\end{array}$ & 90 & $\begin{array}{l}77.0 \pm \\
6.0\end{array}$ & & & & \\
\hline & $\begin{array}{l}\text { Tropical } \\
\text { (Tr) }\end{array}$ & $\begin{array}{l}F . \\
\text { phillyreoides }\end{array}$ & 90 & $\begin{array}{l}79.0 \pm \\
6.8\end{array}$ & & & 0.59 & 0.59 \\
\hline & & $\begin{array}{l}\text { M. ge- } \\
\text { ometrizans }\end{array}$ & 90 & $\begin{array}{l}87.0 \pm \\
3.8\end{array}$ & & & & \\
\hline \multirow[t]{4}{*}{ Gray fox } & Temperate & A. pungens & 90 & $91.6 \pm 6.1$ & 0.21 & $0.00^{*}$ & & \\
\hline & & $\begin{array}{l}\text { Juniperus } \\
\text { sp. }\end{array}$ & 90 & $\begin{array}{l}82.6 \pm \\
12.4\end{array}$ & & 0.08 & & \\
\hline & Tropical & $\begin{array}{l}F \\
\text { phillyreoides }\end{array}$ & 90 & $\begin{array}{l}92.0 \pm \\
11.3\end{array}$ & & 0.58 & & \\
\hline & & $\begin{array}{l}\text { M. ge- } \\
\text { ometrizans }\end{array}$ & 90 & $82.0 \pm$ & & 0.38 & & \\
\hline \multirow[t]{2}{*}{ Coyote } & Temperate & A. pungens & 2 & $67.0 \pm$ & $0.01^{*}$ & 0.00 & & \\
\hline & & $\begin{array}{l}\text { Juniperus } \\
\text { sp. }\end{array}$ & 6 & $\begin{array}{l}67.0 \pm \\
0.0\end{array}$ & & 0.08 & & \\
\hline \multirow[t]{4}{*}{ Ringtail } & Temperate & $\begin{array}{l}\text { Arbutus } \\
\text { sp. }\end{array}$ & 90 & $\begin{array}{l}70.0 \pm \\
19.8\end{array}$ & 0.24 & 0.19 & & \\
\hline & & $\begin{array}{l}\text { Juniperus } \\
\text { sp. }\end{array}$ & 40 & $\begin{array}{l}79.3 \pm \\
15.1\end{array}$ & & 0.08 & & \\
\hline & Tropical & $\begin{array}{l}F . \\
\text { phillyreoides }\end{array}$ & 90 & $\begin{array}{l}84.0 \pm \\
18.1\end{array}$ & & 0.58 & & \\
\hline & & $\begin{array}{l}M . g e- \\
\text { ometrizans }\end{array}$ & 90 & $\begin{array}{l}75.3 \pm \\
14.6\end{array}$ & & 0.38 & & \\
\hline Bobcat & Temperate & $\begin{array}{l}\text { Juniperus } \\
s p .\end{array}$ & 11 & $54.5 \pm$ & $0.04^{*}$ & 0.08 & & \\
\hline
\end{tabular}




\begin{tabular}{|c|c|c|c|c|c|c|c|}
\hline $\begin{array}{l}\text { Disperser } \\
\text { species } \\
\text { (DS) }\end{array}$ & Forest & $\begin{array}{l}\text { Seed } \\
\text { species } \\
(\mathrm{SS})\end{array}$ & $\begin{array}{l}\text { Seeds } \\
(\mathrm{N})\end{array}$ & $\begin{array}{l}\text { Viability } \\
\text { P-value }\end{array}$ & $\begin{array}{l}\text { Viability } \\
\text { P-value }\end{array}$ & $\begin{array}{l}\text { Viability } \\
\text { P-value }\end{array}$ & $\begin{array}{l}\text { Viability } \\
\text { P-value }\end{array}$ \\
\hline Coati & Tropical & $\begin{array}{l}\text { M. ge- } \\
\text { ometrizans }\end{array}$ & 90 & $90.0 \pm$ & 0.53 & 0.38 & \\
\hline
\end{tabular}

* * Statistically significant differences according to the Dunnett test $(P<0.05)$.

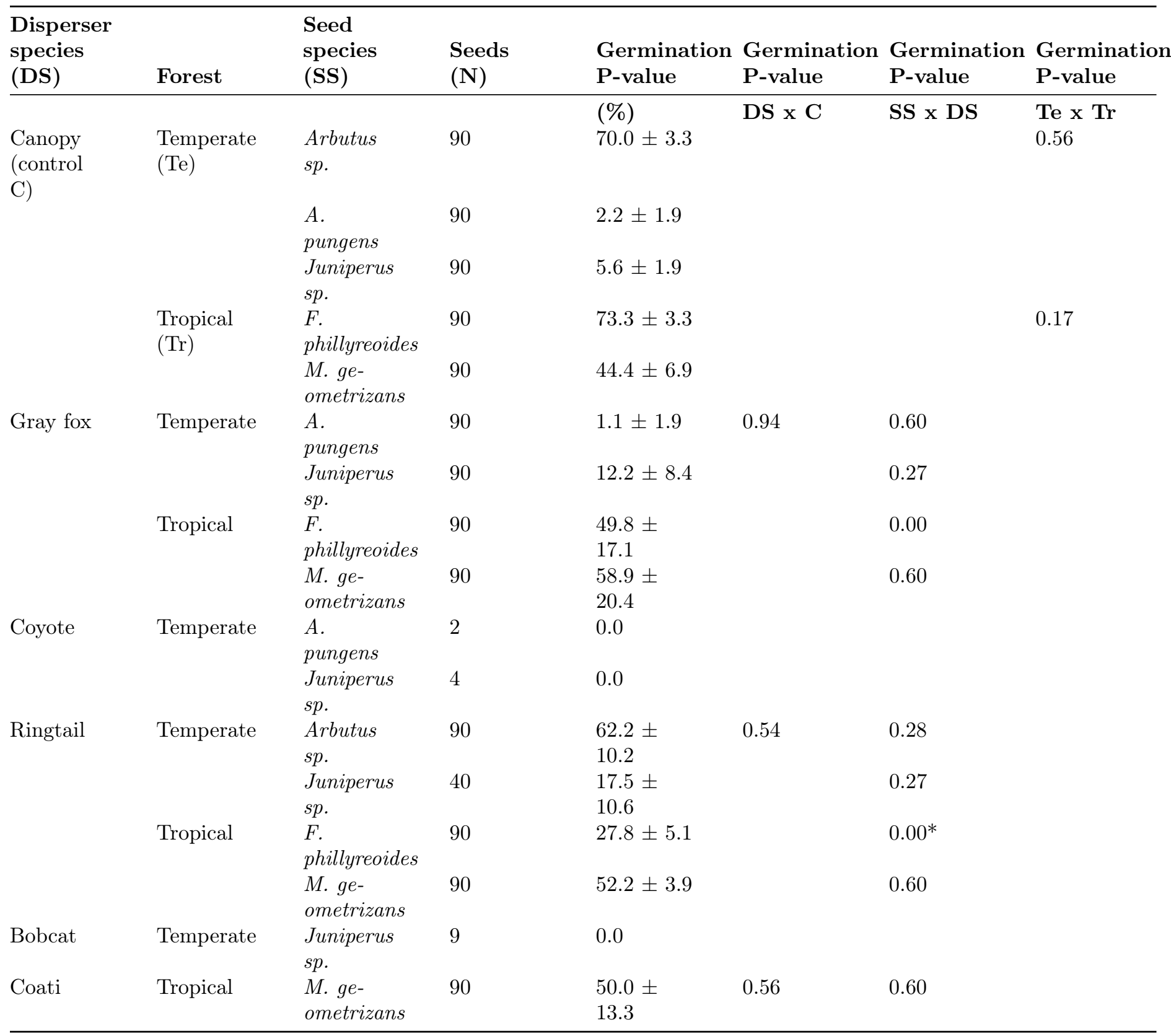


Table 2 Average germination percentages $(x \pm S D)$ of seeds of Arbutus sp ., Arctostaphylos pungensand Juniperus sp ., with their respective animal dispersers, in the temperate forest; and of seeds of Forestiera phillyreoidesand Myrtillocactus geometrizans, with their respective animal dispersers, in the dry tropical forest (both forests are located within the Sierra Fría ANP, Aguascalientes, Mexico).

**Statistically significant differences according to the Dunnett test $(P<0.05)$.

Figure 1. Location of the study areas Monte Grande, Mesa del Águila y del Aserradero, in the temperate forests, and El Terrero de la Labor, in the dry tropical forests, of the Sierra Fría Natural Protected Area, Aguascalientes, Mexico.

Figure 2 Image (x18) of a seed of Juniperus sp. taken with a scanning electron microscope. (A) Seed sections are shown: (1) section opposite the micropyle, (2) central section, and (3) the section on the side of the micropyle, (B) where the three measurements were taken for analysis.

Figure 3 Average dispersion $( \pm S D)$ of forest seeds by animal species and plant species in the temperate forest $(\mathrm{AB})$ and the dry tropical forest $(\mathrm{CD}) .^{\mathrm{a}-\mathrm{b}}$ means with different literals showing statistically significant differences to the Kruskall-Wallis test in the temperate forest and Tukey's HSD in the dry tropical forest $(P<0.05)$.

Figure 4 Seeds of Juniperus $s p$. from X-ray optical densitometry of the seeds from the scats of the different mammals in the temperate forest of the Sierra Fría ANP. Seeds dispersed by: (A) gray fox, (B) coyote, (C) ringtail and (D) bobcat.

Figure 5 Measurements $(\mu \mathrm{m})$ of the average thicknesses $( \pm S D)$ of the seed testas of Juniperus sp . in the temperate forest and of the seed testas of Forestiera phillyreoides in the dry tropical forest, with the seeds obtained from scats in the field of endozoochoric and diploendozoochoric mammals and from the canopy in the Sierra Fría ANP, Aguascalientes, Mexico. ${ }^{a-b}$ means with different literals showing statistically significant differences to Tukey's HSD test $(P<0.05)$. ${ }^{*}$ Statistically significant differences according to the Dunnett test $(P<0.05)$.

Figure 6 Images of seeds of Juniperus sp . of the temperate forest in the Sierra Fría ANP obtained by scanning electron microscopy. (A) Control seed with the protective outer fibrous layer intact (x19). (B) Seed dispersed by the bobcat with the outer layer removed (x18). (C) Seed dispersed by the gray fox with the testa surface detached (x150). (D) Seed dispersed by the ringtail with cracks across the testa (x150).

Figure 7 Images of seeds of Forestiera phillyreoides from the dry tropical forest in the Sierra Fría ANP obtained by scanning electron microscopy. (A) Control seed with a striated layer (x19). (B) Seed dispersed by the gray fox with cracks and holes on the outer layer (x19). (C) Seed dispersed by the gray fox with no damage to the endosperm or the embryo (x19). (D) Seed dispersed by the ringtail with large holes (x40).

\section{DATA ACCESSIBILITY STATEMENT}

The database of the abundance of seeds per scat is available on Dryad (in preparation)

\section{COMPETING INTERESTS STATEMENT}

None declared

\section{AUTHOR CONTRIBUTIONS SECTION}

The study was designed jointly by all the authors. F.A.R.C. led this project and coordinated all aspects of it, including collection of scats, laboratory work, writing and statistical analysis. J.S.R. acquired the funds and contributed significantly throughout the project with writing and corrections. J.J.L.R. contributed to the methodological design, laboratory work, and writing. A.G.V.F. contributed significantly to writing, graphics monitoring, statistical analysis, and corrections. L.I.I.D. contributed to the revision and theoretical foundations.

\section{ACKNOWLEDGMENTS}


We thank the Autonomous University of Aguascalientes for providing the necessary resources for the field work and scanning electron microscopy analysis. We are grateful to V. M. Martínez-Calderón for the technical support during the field work. A special thanks to J. M Pichardo-González and the National Center for Genetic Resources of the National Institute of Forestry, Agricultural and Livestock Research for giving us access to the X-ray equipment for the analysis of forest seeds.

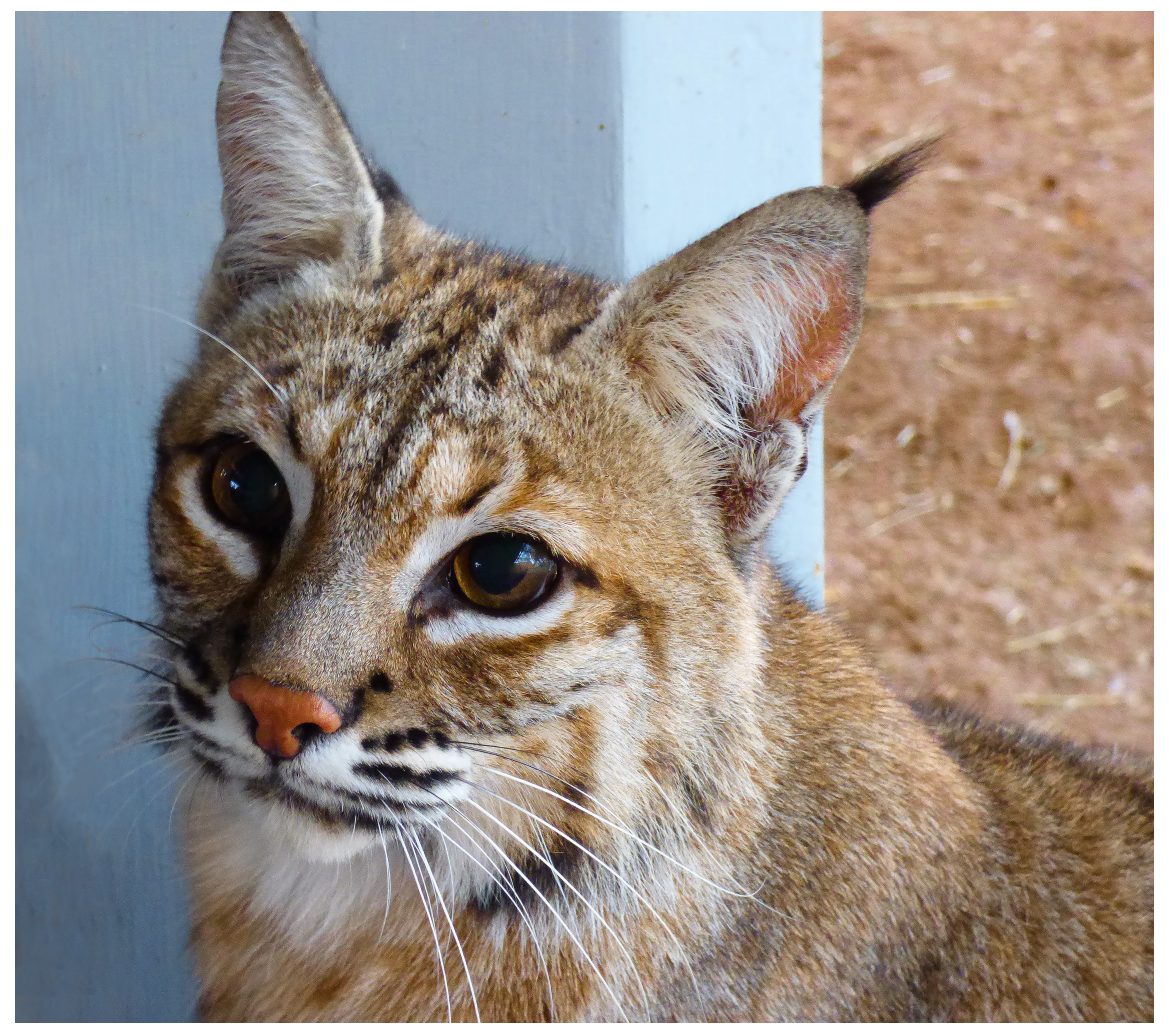



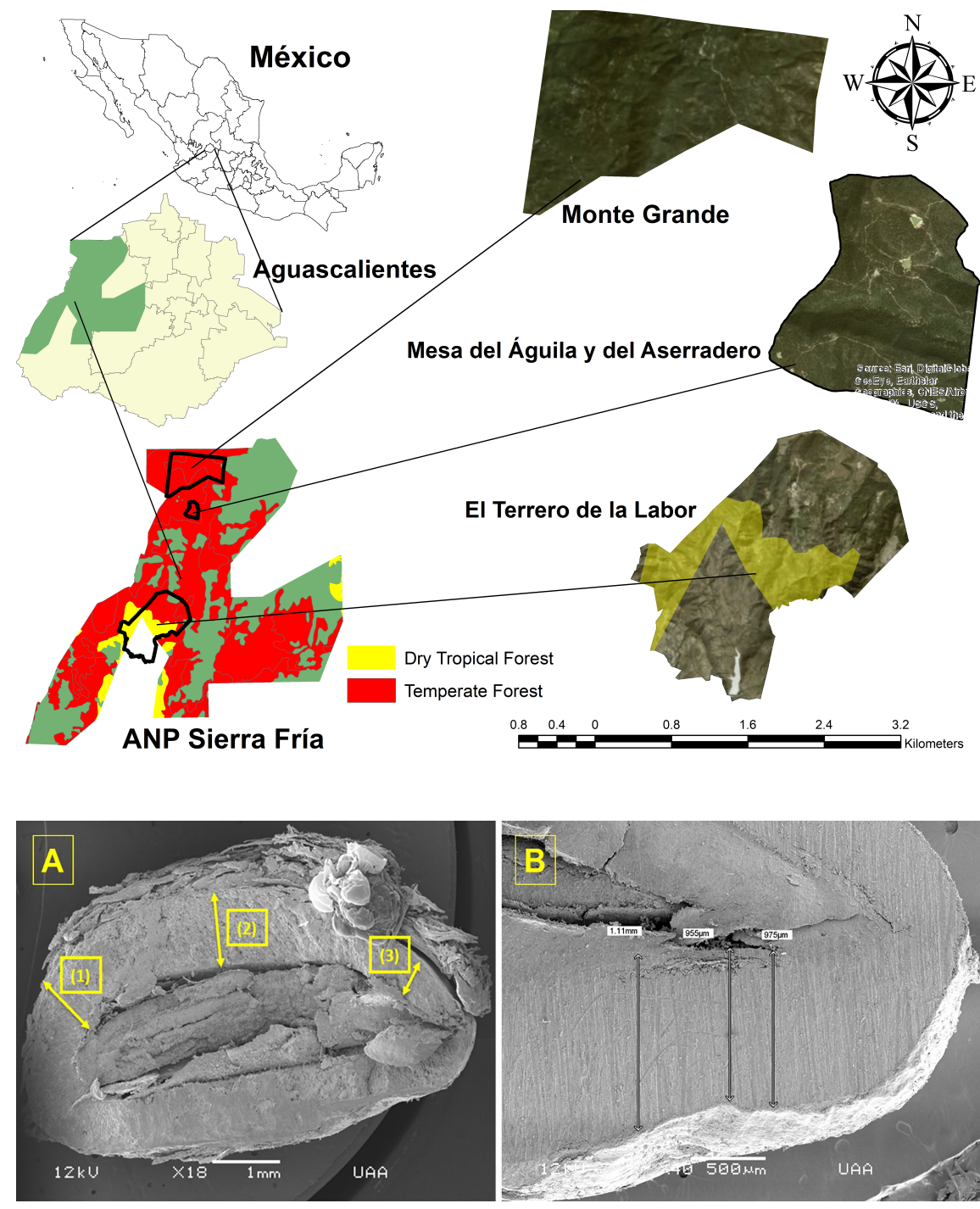
Temperate forest
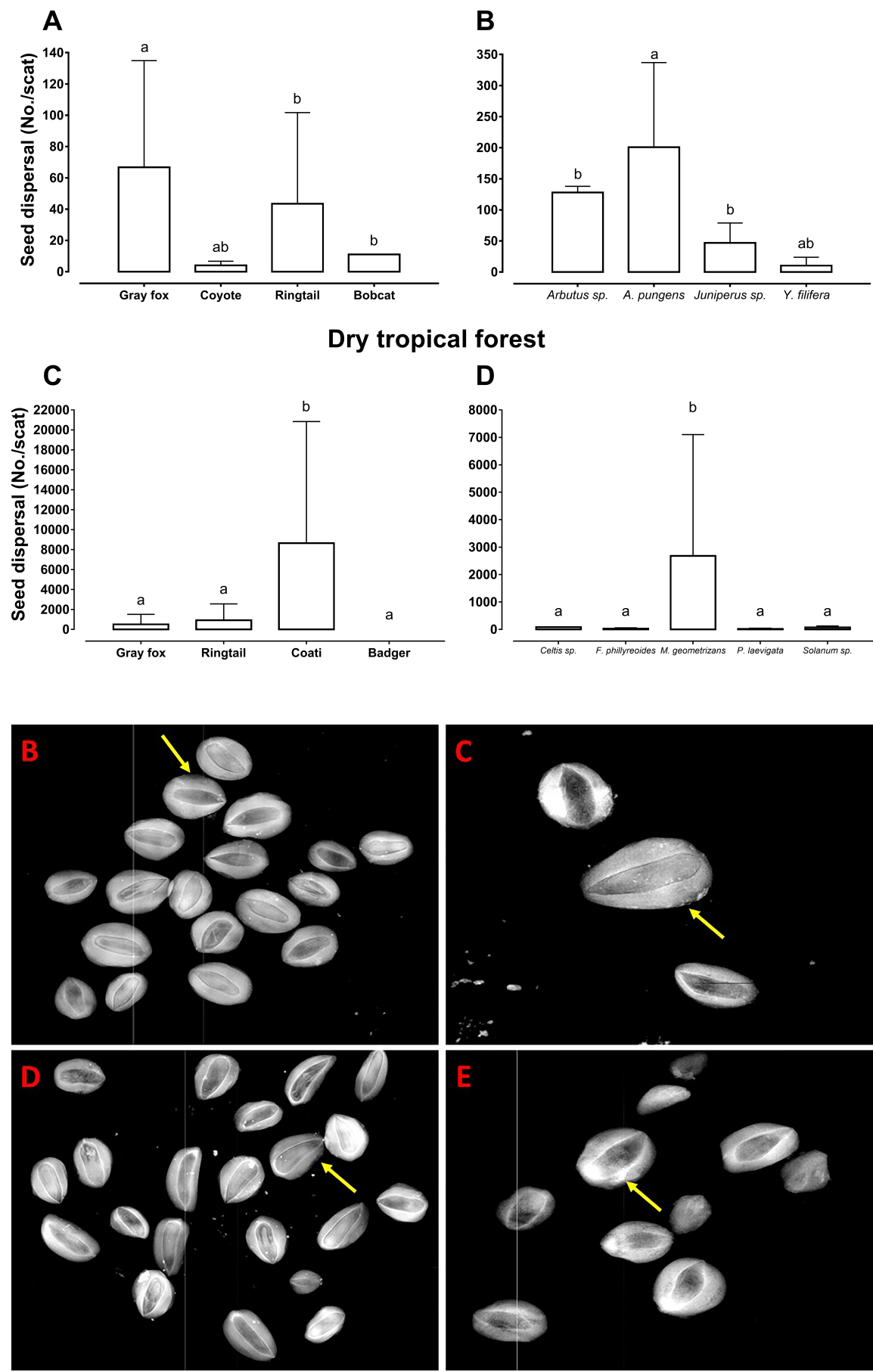

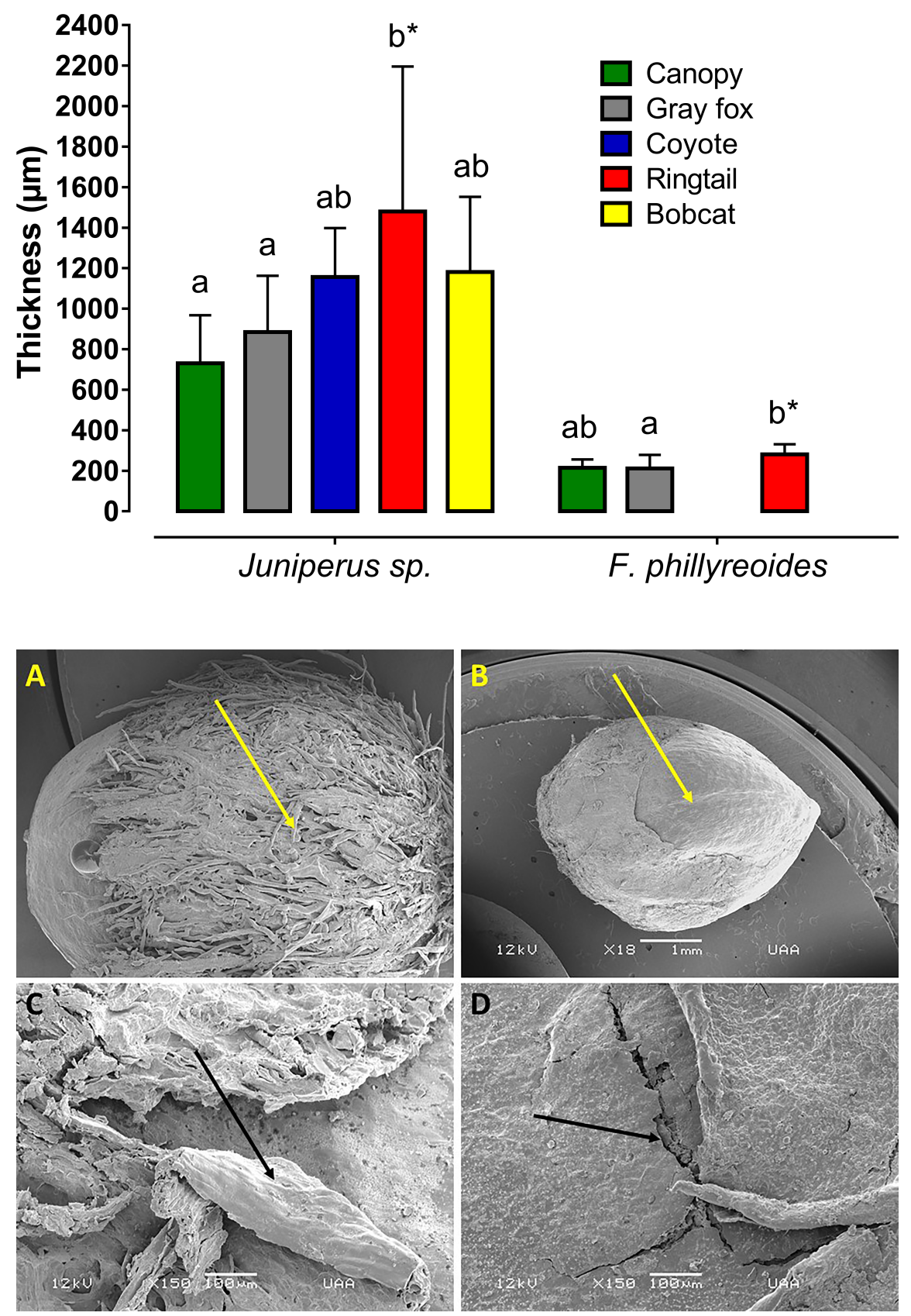

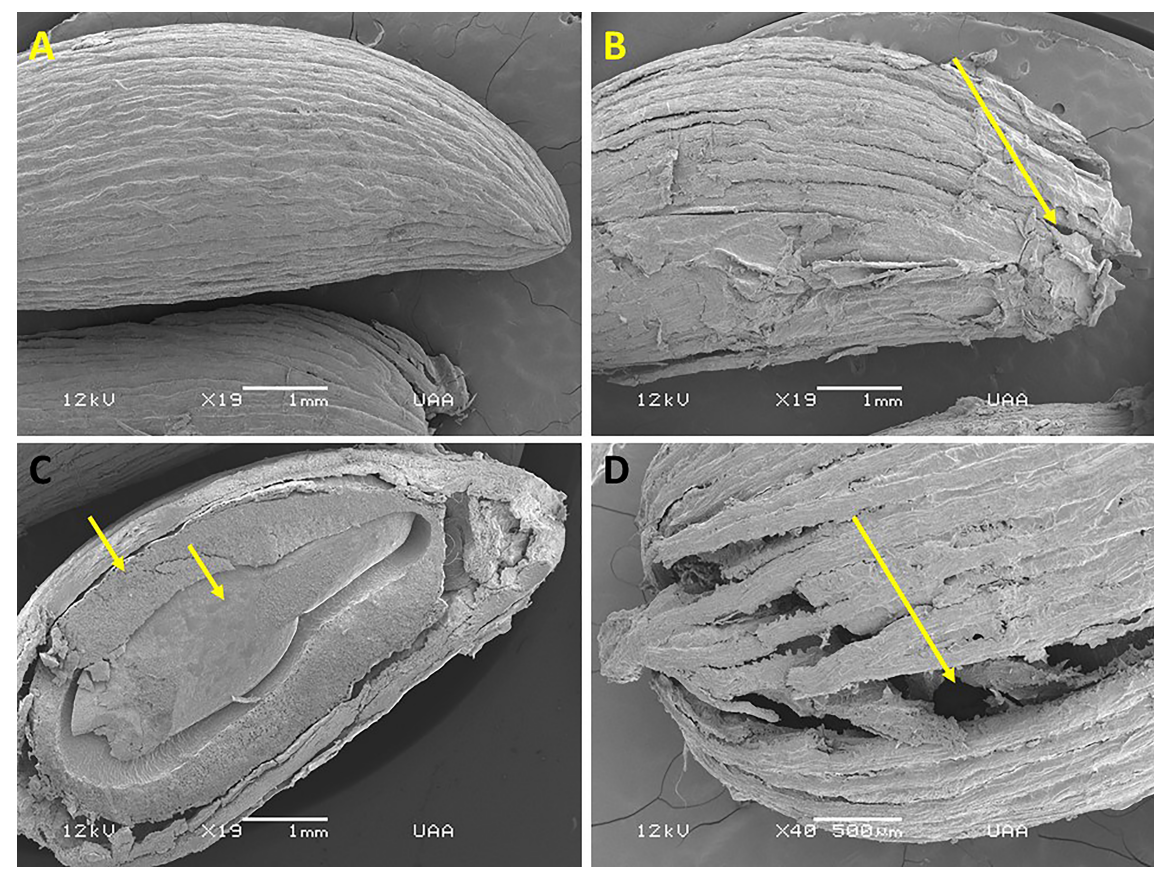